\title{
Publisher Correction: Safety of bacteriophage therapy in severe Staphylococcus aureus infection
}

Aleksandra Petrovic Fabijan (D), Ruby C. Y. Lin D, Josephine Ho, Susan Maddocks, Nouri L. Ben Zakour, Jonathan R. Iredell 1 a and Westmead Bacteriophage Therapy Team

Correction to: Nature Microbiology, https://doi.org/10.1038/s41564-019-0634-z, published online 17 February 2020

In the version of the Article originally published, the following text was mistakenly omitted from the end of the abstract: "Trial Registration: Westmead Hospital Human Research Ethics Committee HREC/17/WMEAD/275; ClinicalTrials.gov: NCT03395769; Clinical Trials Notification (Australian Therapeutic Goods Association): CT-2018-CTN-02372-1.” This has now been corrected.

Published online: 5 March 2020

https://doi.org/10.1038/s41564-020-0698-9

(C) The Author(s), under exclusive licence to Springer Nature Limited 2020 